\title{
Secondary Lahars Triggered by Periglacial Melting at Chimborazo Volcano, Ecuador
}

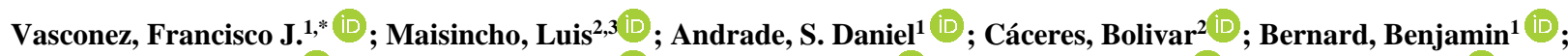

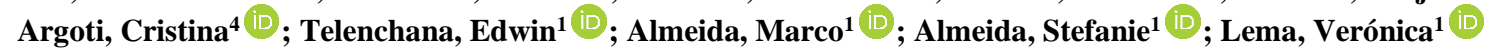 \\ ${ }^{1}$ Escuela Politécnica Nacional, Instituto Geofísico, Quito, Ecuador \\ ${ }^{2}$ Instituto Nacional de Meteorología e Hidrología, Quito, Ecuador \\ ${ }^{3}$ Universidad Regional Amazónica IKIAM, Tena, Ecuador. \\ ${ }^{4}$ Escuela Politécnica Nacional, Facultad de Ingeniería Civil y Ambiental, Quito, Ecuador
}

\begin{abstract}
Periglacial melting processes can provide the water source for secondary lahars triggered by volcanic and/or meteorological phenomena on volcanoes. Between December 2015 and April 2016, four major lahars were reported southeast of Chimborazo volcano (Ecuador). Fieldwork allowed determining the area $(1.67 \pm 0.37 \mathrm{~km} 2)$, volume (3E+05 to 7E+05 m3), peak discharge $(100-150 \mathrm{~m} 3 / \mathrm{s})$ and mean speed $(2-4 \mathrm{~m} / \mathrm{s})$ of these flows, which affected the local infrastructure and threatened several towns downstream (>1000 inhabitants). This case study suggests that anomalous periglacial melting could have been induced by: i) an increase in temperatures at periglacial altitudes partly ascribed to El Niño phenomenon, ii) albedo reduction of the glacier due to ash fallout from Tungurahua volcano (40 km east of Chimborazo) which erupted from 1999 to 2016 and, iii) a slight increase in internal activity at Chimborazo prior and during the lahars occurrence, as evidenced by more seismic events and thermal anomalies. These simultaneous factors could have led to the formation, outburst and/or overflow of superficial and intra-glacier ponds providing the water source to generate lahars on a dormant volcano.
\end{abstract}

Keywords: lahar (debris flow), periglacial melting, glacial outburst, El Niño phenomenon, Chimborazo volcano.

\section{Lahares Secundarios Desencadenados por Fusión Periglacial en el Volcán Chimborazo, Ecuador}

Resumen: Procesos de fusión periglacial pueden ser la fuente de agua necesaria para desencadenar lahares secundarios en volcanes ya sea por fenómenos meteorológicos y/o erupciones volcánicas. Entre diciembre 2015 y abril 2016, cuatro lahares ocurrieron al sureste del volcán Chimborazo (Ecuador). El trabajo de campo permitió determinar el área $(1,67 \pm 0.37 \mathrm{~km} 2)$, volumen $(3 \mathrm{E}+05$ to $7 \mathrm{E}+05 \mathrm{~m} 3)$, caudal máximo $(100$ - $150 \mathrm{~m} 3 / \mathrm{s})$ y velocidad media $(2-4 \mathrm{~m} / \mathrm{s})$ de estos flujos, que afectaron la infraestructura local y amenazaron a varias comunidades aguas abajo (>1000 personas). Este caso de estudio sugiere que el derretimiento anómalo de los periglaciares del Chimborazo pudo haber sido inducido por: i) un incremento en la temperatura superficial a alturas glaciares que fue parcialmente vinculado al fenómeno de El Niño, ii) una reducción del albedo del glaciar debido a la caída de ceniza del volcán Tungurahua (40 km al Este del Chimborazo) que estuvo en erupción desde 1999 hasta 2016 y, iii) un ligero incremento en la actividad interna del Chimborazo antes y durante la ocurrencia de los lahares, evidenciado por un aumento en el número de eventos sísmicos y la aparición de anomalías termales. Estos factores de forma simultánea pudieron facilitar la formación, estallido y/o derrame de lagunas superficiales e intra-glaciales proveyendo la fuente de agua necesaria para generar lahares secundarios en un volcán sin procesos eruptivos en curso.

Palabras clave: lahares, fusión periglaciar, estallido glaciar, fenómeno de El Niño, volcán Chimborazo.

\section{INTRODUCTION}

In Ecuador, debris flows are usually related to ongoing volcanic eruptions (e.g. Jones et al., 2015; Mothes et al., 2004; Pistolesi et al., 2014; Sierra et al., 2019). However, they occur on any type of mountains as has been observed in the Alps and the Cordillera Blanca of Peru (e.g. Ames-Márquez \& Francou,
1995; Chiarle et al., 2007; Lliboutry et al., 1977; Rebetez et al., 1997). A special type of debris flows, known as lahars, are water-saturated volcanic debris and mud flows generated on the high flanks of a volcano or hill, which flow downslope driven by gravity (Vallance, 2005; Waitt, 2013; Mulas et al., 2019). According to Vallance and Iverson (2015), this phenomenon can occur: i) during a pyroclastic flow-forming 
eruption due to partial glacial melting or the disruption of a crater lake (primary lahars), or ii) by heavy rainfalls, outbursts of trapped subglacial water, extreme glacial thawing due to weather conditions and seismic events which mobilize preexisting water-saturated deposits (Barriga-López, 2015; Vasconez et al., 2017). The latter one, known as secondary lahars, are much more common and smaller in volume than the former (Jones et al., 2015). In addition, Pierson et al. (1996) described two main simplified sedimentological types of lahars, which can be distinguished according to their solid concentration: i) hyperconcentrated flows, from 20 to $60 \mathrm{vol} \%$ of sediments, and ii) debris flows, $>60 \mathrm{vol} \%$ of solid particles. Tropical glaciers can be the water-source for lahar formation related to volcanic or meteorological phenomena as was previously described. Chimborazo (6263 masl, $1.47^{\circ} \mathrm{S}$, $78.81^{\circ} \mathrm{W}$ ) is a potentially active, ice-capped volcano (Jordan and Hastenrath, 1998; Barba et al., 2008; Cáceres, 2010; Samaniego et al., 2012) located in the Ecuadorian Western Cordillera, $150 \mathrm{~km}$ southwest of the capital city, Quito. During the Holocene, it had at least seven eruptive periods between 8000 and 1000 BP (Barba et al., 2008). These events produced limited tephra fall, pyroclastic density currents and lahars. Based on radiocarbon records, Samaniego et al., (2012) proposed an eruptive recurrence of 1000 years, with the last eruption having taken place between the early part of the $5^{\text {th }}$ century ( AD 420) and the end of the $7^{\text {th }}$ century (Barba et al., 2008). Based on deposits of these past eruptions, a hazard map of Chimborazo volcano was published in 1990 (Beate et al. , 1990). In addition, three moraine groups were recognized at the high flanks of the volcano (Samaniego et al., 2012). The moraines are at the top of lava flows dated at $30 \pm 3 \mathrm{ka}$ (Bablon et al., 2019) and therefore, they were formed during the Last Glacial Maximum (LGM), Younger Dryas and Neo-Glacial periods, respectively (Barba et al., 2008; Samaniego et al., 2012).

On the early morning of 1 December 2015, a secondary lahar occurred on the southeastern flank of Chimborazo without any associated rainfall. The lahar descended down the Yamborumi drainage (Figure 1, Online Resource 1), which is fed by the $13^{\text {th }}$ glacier tongue and dead ice of Chimborazo at $4912 \mathrm{~m}$ asl, causing damage to a section of a pipeline, a bridge, roads and railway infrastructures. The flow also destroyed irrigation water channels and farmlands used for agricultural and livestock purposes. Four more similar events occurred by March 2017 (Online Resource 2), directly threatening downstream towns such as Santa Lucia de Chuquipogyos and Calshi ( 1000 inhabitants) and could have also represent a potential hazard for critical infrastructure and larger cities such as San Andrés and Guano (Figure 1).

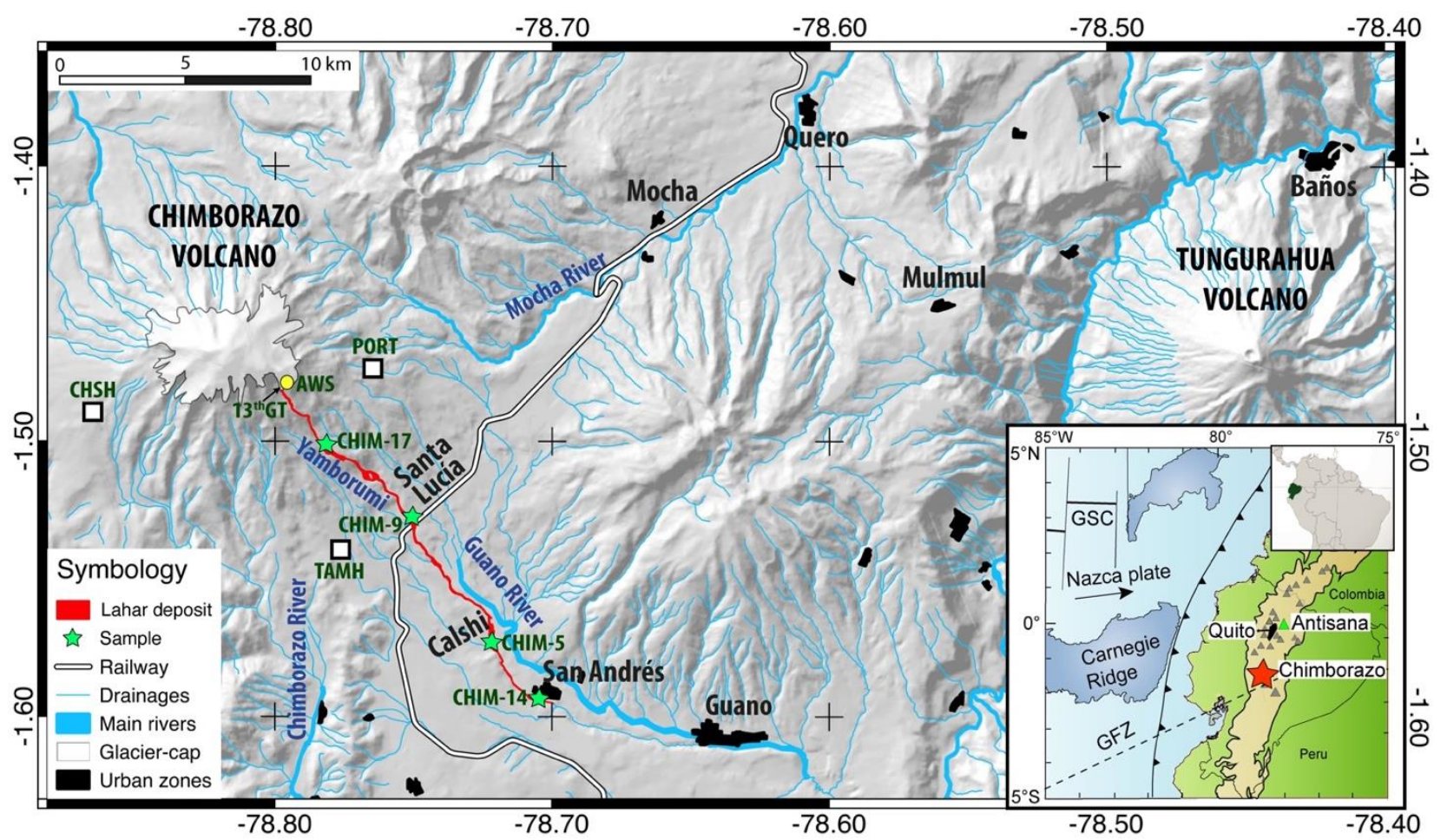

Figure 1. Map of Chimborazo and Tungurahua volcanoes with location of the 2015-2016 lahar deposits in red. White squares are seismic stations and the yellow circle is the automatic weather station (AWS) at the foot of the $13^{\text {th }}$ glacier tongue of Chimborazo volcano installed in December 2016 . Inset shows the main geodynamic structures, GFZ: Grijalva fracture zone, GSC: Galapagos spreading center, Quito city and Antisana and Chimborazo volcanoes.

The aim of the present manuscript is to characterize the lahars that flowed along the Yamborumi drainage and to explore some possible triggering mechanisms for periglacial melting (glacier and dead ice) which could have provided the water source for the documented lahar events.

\section{METHODS AND DATA PROCESSING}

During fieldwork carried out in May 2016, the bulk deposits of four lahars that occurred on 1 and 6 December 2015, 9 March and 20 April 2016, were mapped. This information allowed estimating peak discharge, mean speed, cumulative volume, grain size distribution and componentry portions. Additionally, we used meteorological (weather time-series) 
and volcanological (seismic and thermal images) data, acquired by the official monitoring institutions.

\subsection{Lahar characterization}

Deposition (debulking) and erosion (bulking) zones were identified according to slope and lithofacies criteria, which include sedimentary structures and grain size distribution based on field observations and laboratory analyses. Additionally, 33 thickness measurements were used to estimate the cumulative volume using the Voronoi interpolation (Okabe et al. , 2000). After that, the total volume was divided by four and a $\pm 50 \%$ error was included. Finally, due to the lack of further quantitative information at the time of the lahar occurrence, local news reports (Online Resource 3) were used to assign a more accurate volume percentage to each individual lahar based on the damage produced. In addition, mean speed and peak discharge were estimated using the super-elevation principle in a curved channel (Costa and Williams, 1984; Pierson, 1985). Furthermore, we performed grain size distribution (GSD) analysis on the lahar matrix, from $-5 \phi(32 \mathrm{~mm})$ to $5 \phi(<63 \mu \mathrm{m})$ (ASTM, 2011), for four samples spaced 4 - 5 kilometers from each other (Figure 1), in order to determine the lithofacies type in the matrix fraction according to the diagram proposed by Scott et al., (1995). Finally, componentry analysis was carried out in the most representative fraction resulting of the GSD analysis according to the methodology described by Eychenne and Le Pennec, (2012).

\subsection{Data from monitoring activities}

\subsubsection{Meteorological factors}

- At the time of lahar occurrence, no automatic weather station (AWS) had been installed at Chimborazo. The first AWS located 4430 masl at the foot of the $13^{\text {th }}$ glacier tongue (Figure 1), recorded weather-time series from December 2016 to June 2017 (7 months) because of logistical and operational issues. Thus, in order to quantify weather conditions at Chimborazo before the lahars and expand the available data, meteorological data of Antisana volcano were used. Antisana (5704 masl, $0.48^{\circ} \mathrm{S}, 78.48^{\circ} \mathrm{W}$ ) is an ice-capped volcano located $130 \mathrm{~km}$ to the northeast of Chimborazo (see inset in Figure 1) and its AWS is installed at 4900 masl (Maisincho, 2015). The data from Chimborazo and Antisana were compared on a monthly basis in order to find correlations between both time series.

- An orthophoto taken by the Instituto Geográfico Militar (IGM) in January 2016 and ground control points using GPS linked to the national geodetic network were used to quantify Chimborazo's ice-cap area according to the methodology proposed by the World Glacier Monitoring Service (Müller et al., 1977; Cogley, 2009). The area obtained was compared with previous measurements in order to determine the whole glacier retreat over time and the current area covered by the $13^{\text {th }}$ glacier tongue of Chimborazo.

\subsubsection{Volcanic factors}

- Tungurahua (5016 masl, $\left.1.47^{\circ} \mathrm{S}, \quad 78.44^{\circ} \mathrm{W}\right)$, a stratovolcano located $40 \mathrm{~km}$ to the east of Chimborazo (Figure 1), erupted from October 1999 to March 2016 (IGEPN, 2018). The activity was characterized by moderate explosions which generated transient ash-clouds and sporadic pyroclastic density currents (Arellano et al., 2008; Samaniego et al., 2011; Eychenne and Le Pennec, 2012; Hall et al. , 2015; Mothes et al. , 2015; Hidalgo et al. , 2015; Gaunt et al. , 2019). The prevailing east winds (Parra et al., 2016) resulted in ash fallout in distant locations such as Quero, Mocha and Chimborazo glacier (Figure 1). On 11 November 2015, Tungurahua began a new eruptive phase producing one of the largest ash emissions since 2010 (IGEPN, 2015). Once the eruption ended, ash dispersion and accumulation on Chimborazo's glacier were estimated based on 54 ashmeter collectors (Bernard, 2013) located around the volcano (Online Resource 4). Isomass maps of this eruptive phase were obtained according to the methodologies and tools proposed by several authors (Bonadonna and Houghton, 2005; Bonadonna and Costa, 2013; Mastin et al., 2013).

- Volcanic unrests are associated with an increase in: seismic activity (number and magnitude), gas emissions, ground deformation and/or hydrothermal activity (NAS, 2017). Seismic swarms may precede eruptions (McNutt and Roman, 2015). Three seismic stations monitor Chimborazo: CHSH, PORT and TAMH, located at the volcano's western, eastern and southern flank, respectively (Figure 1). These stations have been recording seismic activity since 2014 . In addition, thermal images obtained during nine overflights between 2002 and 2017 were analyzed to detect atypical superficial temperatures at the volcanic edifice.

\section{RESULTS}

\subsection{Lahar characterization}

The lahar deposits from December 2015 to April 2016 covered an area of $1.67 \pm 0.37 \mathrm{~km}^{2}$, of which $0.8 \mathrm{~km}^{2}$ were used as farmland and $0.3 \mathrm{~km}^{2}$ were Andean grassland "páramo" and pine forests. The lahars flowed $18 \mathrm{~km}$ downstream reaching San Andrés town (2970 masl, Figure 1) with an average slope from the source of $15 \%$.

Nine zones were defined along the Yamborumi ravine (Figure 2a) during the fieldwork, based on stream slope, lahar lithofacies and average deposit thickness. Zones 1 and 3 (Figure $2 \mathrm{~b} \& 2 \mathrm{c}$ ) correspond to bulking sectors due to high slopes (35-45\%) and significant channel incision. These zones were excluded from the volume estimation because the lahars flowed restricted to the narrow and steep ravine and did not leave any significant deposits. The remaining zones, 2 and from 4 to 9 are debulking sectors.

Zone 1 is the source region of these lahars. Zone 2 is a $2 \mathrm{E}+05 \mathrm{~m}^{2}$ flat surface, where lahars deposited most of their big boulders and sediments (Figure 2b). After that, in zone 3 (Figure 2c), the lahars incised though a thick moraine deposit, reincorporating sediments, which were later on deposited in 
zones 4, 5 and 6 (up to $8 \mathrm{~km}$ from the source). GSD from samples CHIM-17 and CHIM-9, in zones 2 and 6, respectively, show a non-cohesive debris flow behavior (Figure 3a), i.e. gravel and coarse sand matrix-supported facies without sedimentary structures and which includes blocks of up to 1-2 meters in diameter as shown in the video Online Resource 2. The maximum deposit thickness measured in these areas ranges from 2 to 4 meters (Table 1). Finally, zones
7, 8 and 9, located more than $9 \mathrm{~km}$ away from the source (Figure 2a), are areas where the flows lost their capacity to carry coarse debris and progressively became hyperconcentrated flows, as shown in Figure 3a (samples CHIM-5 and CHIM-14). They are characterized by fine sand matrix-supported facies with ripple structures. The thicknesses measured in here are the smallest ones (Figure $2 \mathrm{~d}$ ) between 0.5 and 0.7 meters (Table 1 ).

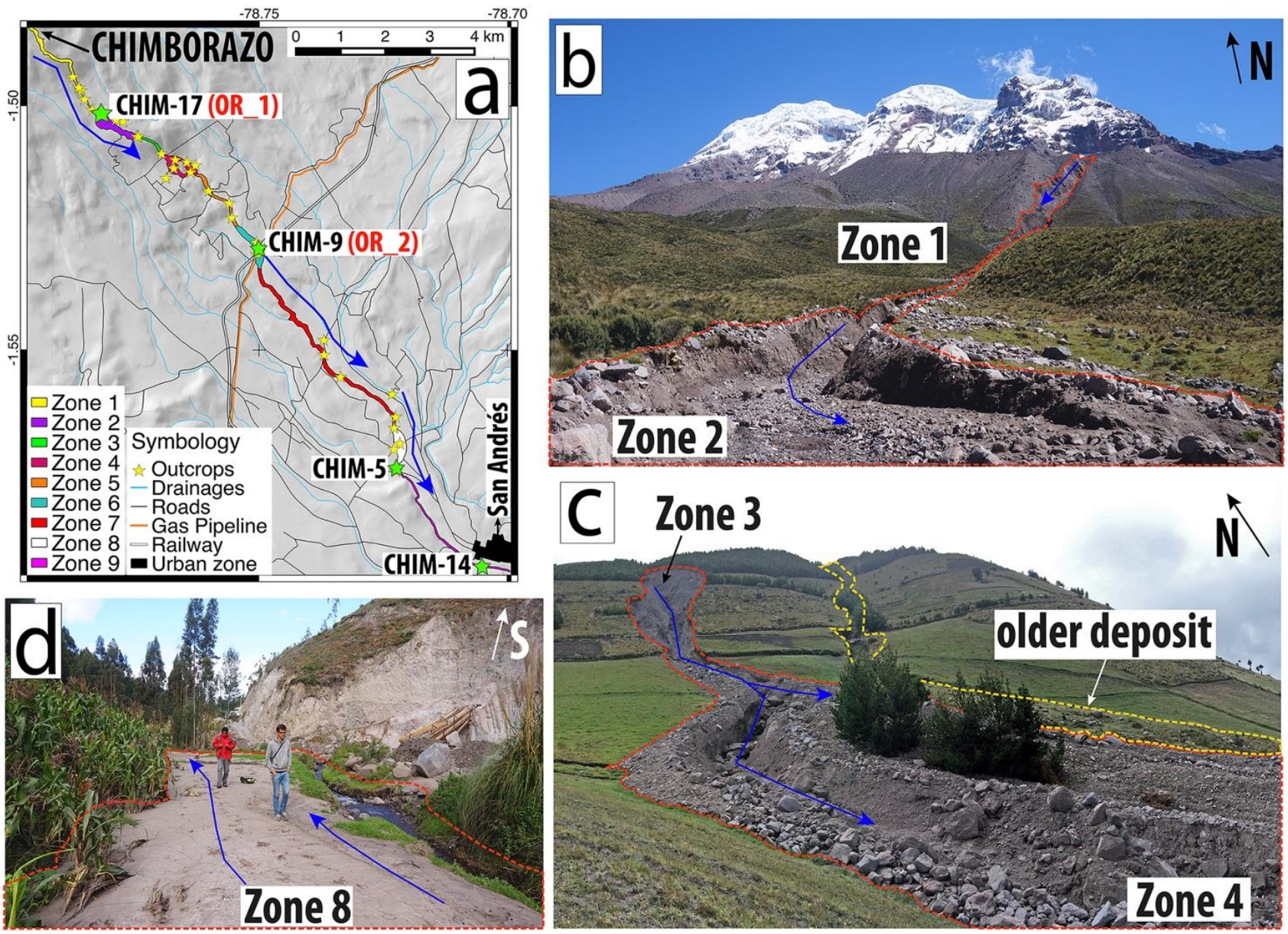

Figure 2. a) Zoning of the lahar deposit according to slope, lithofacies and average thickness criteria, b) zone 1 is the source region and zone 2 is the first deposition area, c) zone 3 is a bulking sector and zone 4 is a debulking area, where the lahars reached their maximum thickness. d) Zone 8 is a debulking area where the lahars became hyperconcentrated. Blue arrows indicate the direction of the flow and the red and yellow dashed lines the lahar edges. For online resources (OR_\#) see supporting material.

Table 1. Characteristics of the nine-lahar zones. $\mathrm{B}=$ bulking and $\mathrm{D}=$ debulking.

\begin{tabular}{|c|c|c|c|c|c|}
\hline \multirow[t]{2}{*}{ Zone } & \multirow{2}{*}{$\begin{array}{c}\text { Area } \\
\left(\mathbf{E}+05 \mathbf{~ m}^{2}\right)\end{array}$} & \multicolumn{2}{|c|}{ Thickness (m) } & \multirow{2}{*}{$\begin{array}{c}\text { Volume } \\
\left(\mathbf{E}+05 \mathbf{~ m}^{3}\right)\end{array}$} & \multirow[t]{2}{*}{ Type } \\
\hline & & $\begin{array}{c}\text { River- } \\
\text { bed }\end{array}$ & $\begin{array}{l}\text { River } \\
\text { side }\end{array}$ & & \\
\hline 1 & 1.87 & 0 & 0 & 0 & $\mathrm{~B}$ \\
\hline 2 & 2.16 & 2 & 0.5 & 2.56 & $\mathrm{D}$ \\
\hline 3 & 0.42 & 0 & 0 & 0 & $\mathrm{~B}$ \\
\hline 4 & 1.92 & 4 & 0.7 & 5.04 & $\mathrm{D}$ \\
\hline 5 & 1.12 & 2 & 0.7 & 1.54 & $\mathrm{D}$ \\
\hline 6 & 1.62 & 3.3 & 0.7 & 2.81 & $\mathrm{D}$ \\
\hline 7 & 4.21 & 2.2 & 0.7 & 5.24 & $\mathrm{D}$ \\
\hline 8 & 1.77 & 1.2 & 0.5 & 1.60 & $\mathrm{D}$ \\
\hline 9 & 1.56 & 1.2 & 0.7 & 1.57 & D \\
\hline Total & 16.68 & & & 20.36 & \\
\hline
\end{tabular}

The four major lahars in the study period have an estimated volume of $20 \mathrm{E}+05 \mathrm{~m}^{3}$, while individual ones range from
$3 \mathrm{E}+05$ to $7 \mathrm{E}+05 \mathrm{~m}^{3}$ (Table 2). The largest lahars occurred on 1 December 2015 and 29 April 2016, the latter being the only one accompanied by heavy rainfall, according to local reports. Peak discharges of $51-158 \mathrm{~m}^{3} / \mathrm{s}$ and average speeds of $2-4 \mathrm{~m} / \mathrm{s}$ were estimated for the largest flows, whose deposits were clearly distinguishable during fieldwork.

Table 2. Volume, mean speed (MS) and peak discharge (PD) for each lahar

\begin{tabular}{lcccc}
\hline $\begin{array}{c}\text { Date } \\
(\mathbf{d d} / \mathbf{m m} / \mathbf{y y})\end{array}$ & $\begin{array}{c}\text { \% of the } \\
\text { total volume }\end{array}$ & $\begin{array}{c}\text { Volume } \\
\left.\mathbf{( m}^{\mathbf{3}}\right)\end{array}$ & $\begin{array}{c}\text { MS } \\
\mathbf{( m / s})\end{array}$ & PD $\left(\mathbf{m}^{\mathbf{3} / \mathbf{s})}\right.$ \\
\hline $01 / 12 / 2015$ & 30 & $6 \mathrm{E}+05$ & 4 & $90-100$ \\
$06 / 12 / 2015$ & 20 & $4 \mathrm{E}+05$ & - & - \\
$09 / 03 / 2016$ & 15 & $3 \mathrm{E}+05$ & - & - \\
$29 / 04 / 2016$ & 35 & $7 \mathrm{E}+05$ & $2-4$ & $51-158$ \\
\hline Total & 100 & $20 \mathrm{E}+05$ & & \\
\hline
\end{tabular}


Finally, componentry analysis of the $2 \phi(250 \mu \mathrm{m})$ fraction, which we considered the most representative in the matrix fraction according to GSD analyses (Figure 3b), allowed identifying: $44.6 \%$ of black shiny and gray andesites and dacites, $33.6 \%$ of free crystals (pyroxene and plagioclase), $21.7 \%$ of oxidized red lithics and scoria and $0.33 \%$ of organic material (Figure 3c). These materials are thought to have been derived from the three groups of moraines described by Samaniego et al., (2012) at zones 1 and 3 (Figure 2b \& 2c), and from Chimborazo's previous pyroclastic deposits which are mainly tephra falls and surge units associated to the Holocene eruptive activity detailed in Barba et al., (2008).

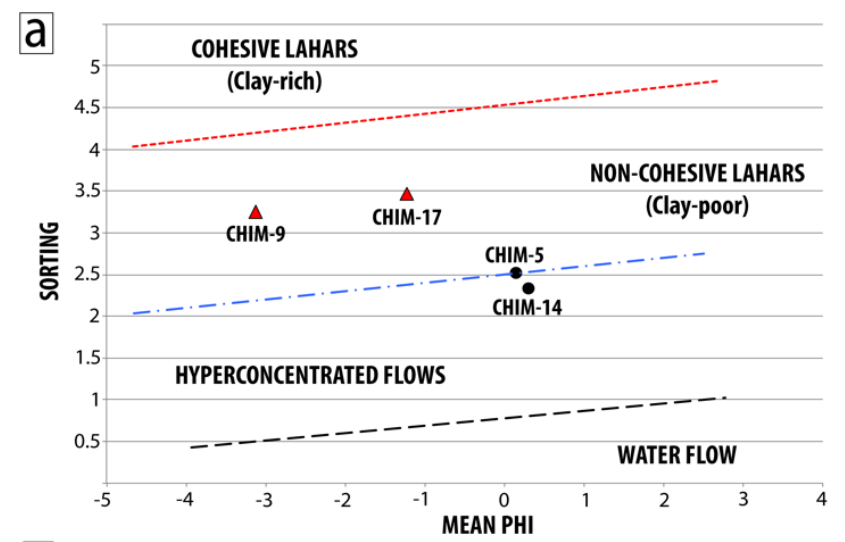

\section{b}
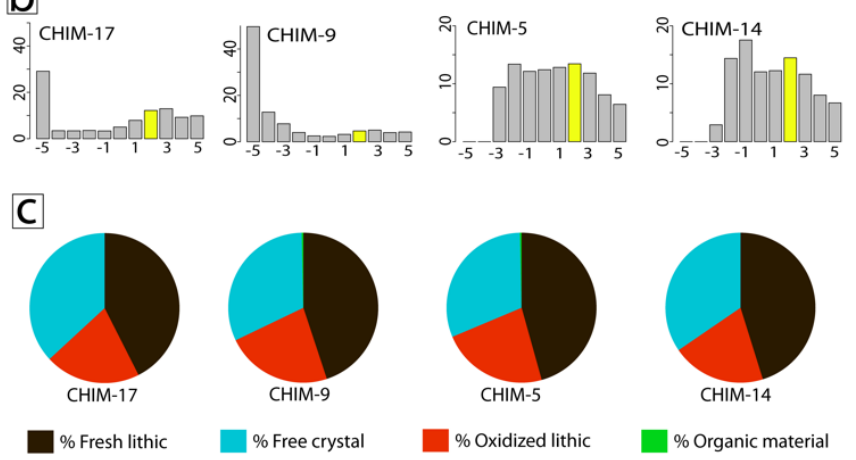

Figure 3. a) Mean grain size vs. sorting based on Scott et al. (1995), b) Grain size distribution, in yellow the chosen representative fraction and, c) componentry analysis on that chosen fraction.

\subsection{Results from surveillance activities}

\subsubsection{Meteorological factors}

Table 3 compares several meteorological data of Chimborazo's and Antisana's AWS during the period from December 2016 to June 2017. Incident shortwave radiation (ISR), incident longwave radiation (ILR), air temperature (T), relative humidity of the air (RH) and wind speed (WS) display high correlation $\left(\mathrm{R}^{2}\right)$ index ranging from 0.75 to 0.9 at glacier altitudes. Therefore, we assumed that Antisana's weather time-series could be used as an approximation to assess the impact of weather fluctuations at Chimborazo at the time when the lahars occurred.
Table 3. Correlation between the meteorological parameters measured at Chimborazo and Antisana volcanoes at glacier altitudes in monthly levels. $(*)$ shows high correlation $\left(\mathrm{R}^{2}\right)$

\begin{tabular}{lll}
\hline Variable & Symbology & $\mathrm{R}^{2}$ \\
\hline *Incident shortwave radiation & ISR & 0.91 \\
Reflected shortwave radiation & RSR & 0.45 \\
*Incident longwave radiation & ILR & 0.75 \\
Outgoing longwave radiation & OLR & 0.18 \\
*Air temperature & T & 0.87 \\
*Relative humidity & RH & 0.84 \\
*Wind speed & WS & 0.75 \\
Surface temperature & ST & 0.66 \\
\hline
\end{tabular}

Antisana's weather station shows that the year when the lahars occurred was one of the hottest during the 2005-2015 time period (11 years). The mean temperature was $1.4^{\circ} \mathrm{C}$, while temperatures in previous years lay below $1^{\circ} \mathrm{C}$ (Figure $\left.4 \mathrm{a}\right)$. The increase in $\mathrm{T}$ and slight decrease in $\mathrm{RH}$ (Figure $4 \mathrm{~b}$ ) can be linked to the abrupt increase in ISR. Incident shortwave radiation reaches $494 \mathrm{~W} / \mathrm{m}^{2}$, which is $20 \%\left(82 \mathrm{~W} / \mathrm{m}^{2}\right)$ above the mean from 2005 to 2015 (Figure 4c). The WS (Figure 4d) also shows an increasing trend of $2 \mathrm{~m} / \mathrm{s}$ above the mean, reaching $6 \mathrm{~m} / \mathrm{s}$ in 2015. Finally, the annual cumulative precipitation (Figure 4e) shows no significant changes with values of $1045 \mathrm{~mm} / \mathrm{y}$ in 2015 while the mean precipitation at glacier altitudes is $925 \mathrm{~mm} / \mathrm{y}$ (Manciati et al., 2014).
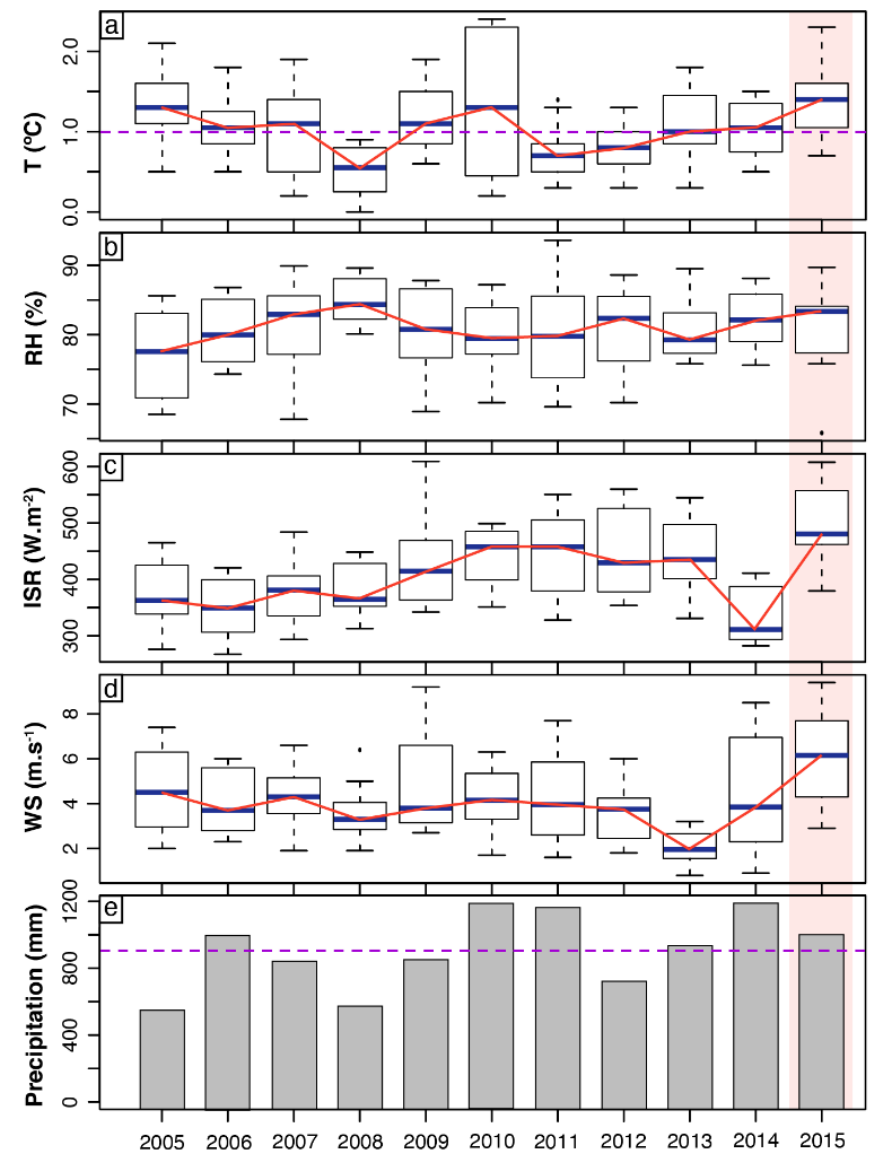

Figure 4. Evolution of the weather variables at Antisana's glacier (4900 m asl) from 2005 to 2015. a) Air temperature (T), b) relative humidity (RH), c) incident shortwave radiation (ISR), d) wind speed (WS) and e) annual cumulative precipitation. Blue lines are the mean of the weather variables, the box is the standard deviation, the red lines show the trend over time and purple line highlights the $1.0^{\circ} \mathrm{C}$ threshold and mean precipitation at glacier altitudes for comparison. 
In 1962, Jordan and Hastenrath (1998) estimated a glacier cap area of $27.7 \mathrm{~km}^{2}$ for Chimborazo. Cáceres (2010) calculated a reduction of $59.8 \%$ for the period from 1962 to 1997 , resulting in an area of $11.82 \mathrm{~km}^{2}$. Here, we estimated $7.63 \mathrm{~km}^{2}$ based on an orthophoto taken in January 2016. At this time, the $13^{\text {th }}$ glacier tongue covered an area of $0.28 \mathrm{~km}^{2}$.

\subsubsection{Volcanic factors}

For Tungurahua's eruption in November 2015, we estimated that $1.83 \mathrm{E}+06 \mathrm{~m}^{3}$ of volcanic ash were released into the atmosphere based on the interpolation of cumulative ash in 54 ashmeters (purple dots in Figure 5b). These data also allowed to identify the average wind direction during the eruption, which drifted to the west, northwest and southwest (Figure 5c). Moreover, we estimated the cumulative volcanic ash to have reached $<100 \mathrm{~g} / \mathrm{m}^{2}$ at the highlands of the eastern flank of Chimborazo volcano, based on kriging.

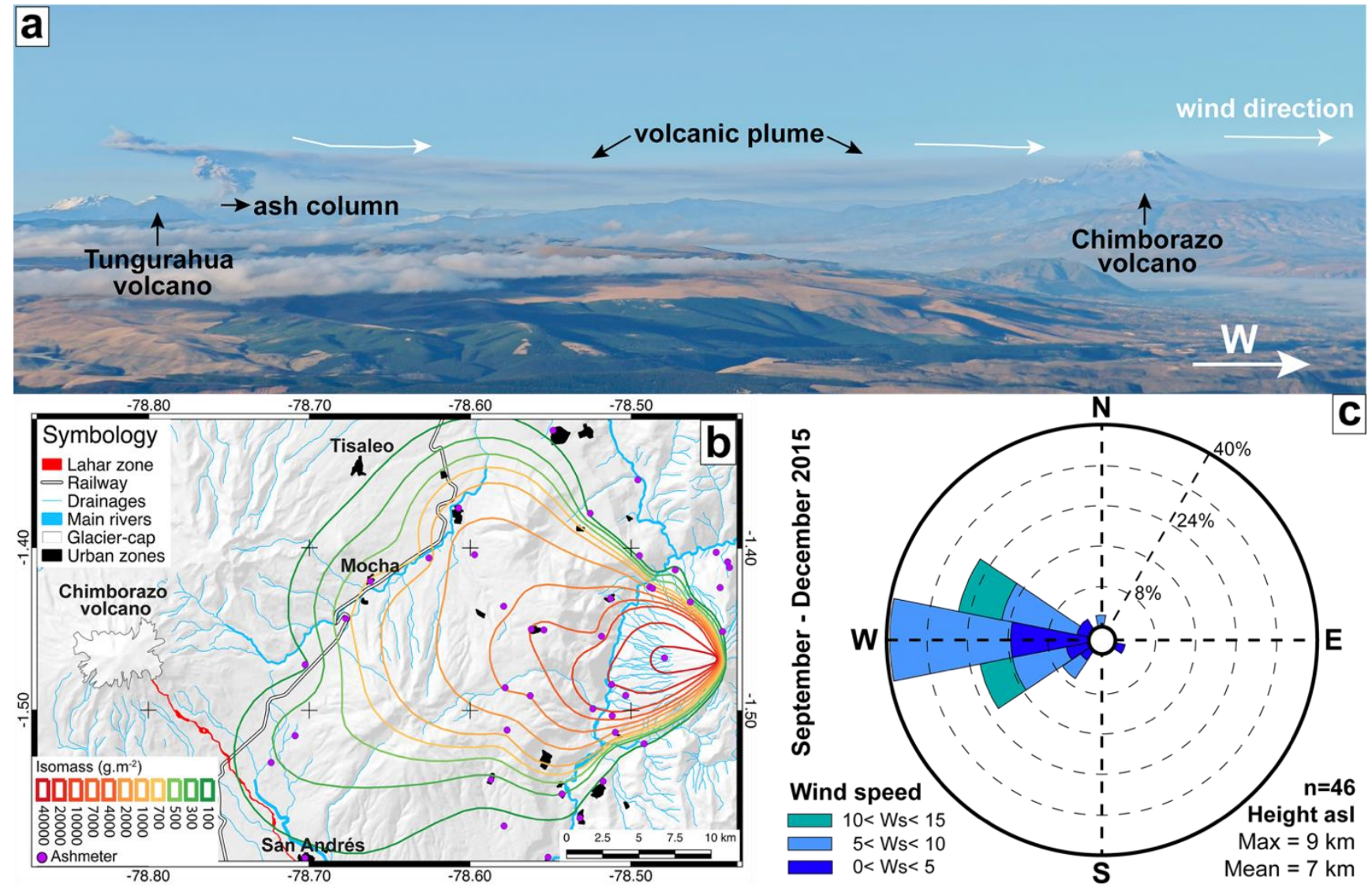

Figure 5. a) Ash emissions from Tungurahua volcano deposited on Chimborazo volcano (photo. 05/09/2013), b) isomass map of Tungurahua eruptive period September-December 2015, c) direction of ash cloud alerts of Tungurahua volcano (46) according to Washington VAAC

(https://www.ssd.noaa.gov/VAAC/ARCH15/archive.html). Most of the volcanic plumes drifted to the west with mean speeds of 5-10 m.s $\mathrm{s}^{-1}$ at $7 \mathrm{~km}$ asl or $2 \mathrm{~km}$ above the crater of Tungurahua.

Figure 6a shows the cumulative number of seismic events per month from March 2014 to May 2017. At the time of the lahar occurrence, an increase in the number of events was recorded. The main peaks were observed in December 2015, March and May 2016 with 41, 27 and 36 seismic events, respectively. For comparison, before (from April 2014 to November 2015) and after lahar occurrence (since August 2016) the medians were of 2 and 7 seismic events per month. Nowadays, the seismic behavior of Chimborazo is not well-known because seismic levels are low, data recording is intermittent and unrest periods have never been reported.
In addition, the analysis of the infrared images obtained during overflights from 2002 to 2015, did not show any thermal anomalies. However, during the overflight on 20 February 2016 (2 months after the first lahar) a thermal anomaly was observed in a crevasse located in the upper southwestern flank of Chimborazo (Figure 6b). The thermal profile shows a maximum apparent temperature of $42.6^{\circ} \mathrm{C}$ (Figure 6c). Nonetheless, because of the location of the anomaly no correlation between the lahars and the localized heating area can be inferred. 


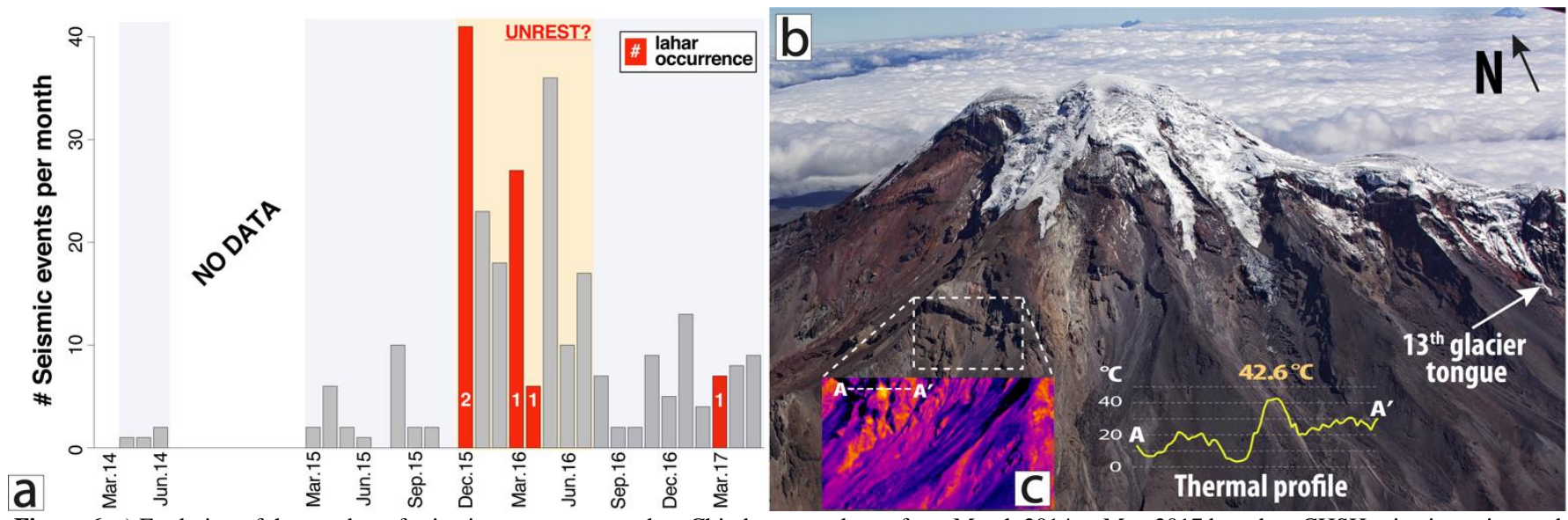

Figure 6. a) Evolution of the number of seismic events per month at Chimborazo volcano from March 2014 to May 2017 based on CHSH seismic station; red bars highlight the lahar occurrence and number of events. b) Aerial view of Chimborazo volcano showing the glaciers of the southwestern flank including the $13^{\text {th }}$ glacier tongue. c) Location of the anomaly and thermal profile A-A'.

\section{DISCUSSION OF THE POTENTIAL TRIGGER MECHANISMS}

Meteorological temporal series show that temperature, incident shortwave radiation and wind speed reached a peak in 2015. Strong winds trigger turbulence in the atmosphere which at glacier altitudes produces sublimation of the ice/snow (Favier et al., 2004). All these factors together can cause a pronounced increase in the glacier-melting rates of Antisana and also Chimborazo volcano. In addition, during 2015, the local and regional climatology was disturbed by the oceanatmospheric phenomenon known as El Niño (ENSO) (Barnard et al., 2017). According to Francou et al., (2004), this phenomenon causes an increase in the energy available to melt ice/snow, and a decrease in the cloud cover and therefore decrease of precipitation and $\mathrm{RH}$ in the Andean region. That implies higher penetration of ISR and an increase in temperature as is observed in the time-series (Figure 4). Additionally, the monthly evolution of the weather variables in 2015 show sustained increases in air temperature at Antisana with peaks of $1.7^{\circ} \mathrm{C}$ and $2.3^{\circ} \mathrm{C}$ in September and December, respectively.

Moreover, tephra accumulation on glaciers could produce albedo reduction because more solar energy is absorbed, inducing melting (Delgado-Granados et al. , 2015). Schotterer et al., (2003) reported a remarkable change in Chimborazo's glacier related to ashfall from Tungurahua in 2000. The ashfall resulted in extreme melting and the formation of penitents and intra-glacier ponds at $28 \mathrm{~m}$ depth beneath the summit. Since then, several more of Tungurahua's eruptions have affected Chimborazo's glacier (Figure 5a), including the November 2015 eruptive phase.

Despite the fact that seismic activity is not well-known at Chimborazo volcano, based on the available data, it is possible to infer that during the period from December 2015 to July 2016 a slight increase in internal activity took place at Chimborazo volcano (Figure 6).

In addition, the residents along the riversides of the Yamborumi ravine observed buoyant ice during the first lahar emplacement on 1 December 2015, while the "Cenit Mountain
Club" reported superficial water-ponds on the $13^{\text {th }}$ Chimborazo glacier tongue at the end of December 2015 (Figure 7a). Additionally, during the overflight performed on 20 February 2016 some kettle holes were observed on Chimborazo's moraine deposits (Figure 7b). Therefore, we conclude that an intense periglacial melting process was ongoing at the time of the lahars occurrence on Chimborazo volcano.

Although the exact melting mechanism remains unknown, based on field observations, meteorological and volcanological evidences, we suggest that: i) the anomalous increase of energy fluxes from the atmosphere linked to ENSO phenomenon, ii) the decrease of glacier albedo due to ash accumulation from Tungurahua volcano and iii) a slight increase in internal activity at Chimborazo shown by more seismic events and thermal anomalies, could all have led to the rapid formation of superficial and intra-glacier water ponds. These, in turn, subsequently burst out incorporating moraines, providing the water and sediment sources to form secondary lahars without associated rainfall nor an eruption.

Similar trigger mechanisms have been suggested for debris flows generated at the Cordillera Blanca in Perú (Lliboutry et al. , 1977b) and more recently at the Himalaya mountain range in India (Nie et al. , 2021; Biswas, 2021).

Importantly, because the published hazard map from 1990 only regards hazards related to eruptive events at Chimborazo, the occurrence of these secondary, eruption-unrelated lahars prompted the elaboration of a new hazard map for Yamborumi ravine (Vasconez et al. , 2016).

Finally, it seems that similar lahar events have occurred in the past near to the Yamborumi drainage, as shown in Figure 2c. Perhaps these phenomena are recurrent in other drainages of the volcano, but they were not reported because no populated areas or infrastructure were affected. In order to prevent future damage to infrastructure and populated areas, further research should focus on the source processes and/or the location of potential ponds that could burst out at Chimborazo volcano and at other Ecuadorian volcanoes. 


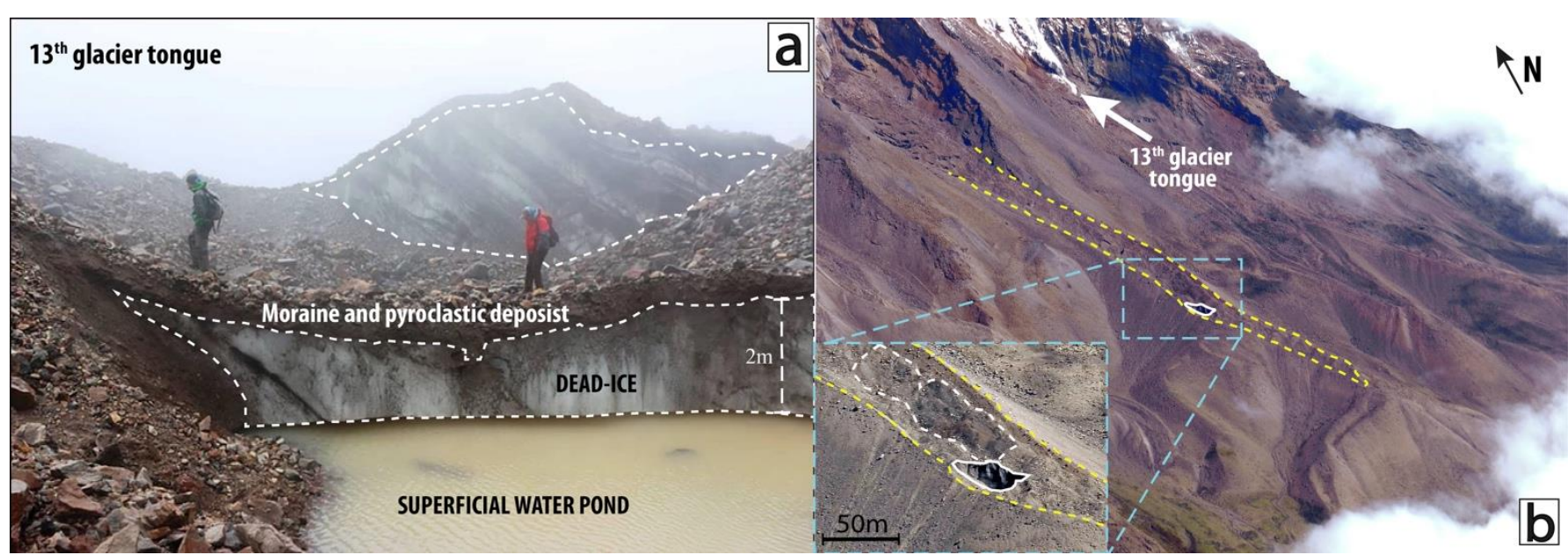

Figure 7. a) Molten dead ice at the 13th glacier tongue of Chimborazo volcano (ph. Jaime Romero), b) kettle holes detected on Chimborazo's dead ice which are covered by moraine deposits.

\section{ACKNOWLEDGEMENTS}

The authors thank the Instituto Geofísico de la Escuela Politécnica Nacional (IG-EPN) and the Instituto Nacional de Meteorología e Hidrología (INAMHI) for the logistical support during the fieldwork campaigns, as well as providing volcanological and meteorological data respectively. We thank "CENIT" Mountain Club especially Jaime Romero who provided the picture displayed in Figure 7a. A special acknowledgment goes to Anais Vásconez Müller who advised in the organization of the manuscript and also to PhD. Pablo Samaniego and Naresh Rana for their suggestions. This research has been conducted in the context of IG-EPN's "Proyecto de Generación de Capacidades para la Emisión de Alertas Tempranas" funded by Secretaria Nacional de Planificación y Desarrollo.

\section{Data availability}

Supporting information can be found alongside the online version of this manuscript. Supporting Videos: Online Resource 1: video of the lahar at the proximal zone 2, Online Resource 2: video of the lahar at zone 6 and Supporting data: Online Resource 3: media reports of Chimborazo lahars and Tungurahua eruption in November 2015. Seismic and meteorological data recorded by IG-EPN and INAMHI can be requested for further analysis and future work at https://www.igepn.edu.ec/ and http://www.serviciometeorologico.gob.ec/, respectively.

\section{REFERENCIAS}

Ames-Márquez, A, Francou, B (1995). Cordillera Blanca: glaciares en la historia. Bull. Inst. fr. études andines. 24(1): 37-64

Arellano, SR, Hall, M, Samaniego, P, et al (2008). Degassing patterns of Tungurahua volcano (Ecuador) during the 1999-2006 eruptive period, inferred from remote spectroscopic measurements of $\mathrm{SO} 2$ emissions. $J$ Volcanol Geotherm Res. 176(1):151-162. https://doi.org/10.1016/j.jvolgeores.2008.07.007

ASTM D (2011) 2487 (2006). Standard practice for classification of soils for engineering purposes (Unified Soil Classification System). Book Stand 4
Bablon, M, Quidelleur, X, Samaniego P, et al (2019). Interactions between volcanism and geodynamics in the southern termination of the Ecuadorian arc. Tectonophysics. 751:54-72. https://doi.org/10.1016/j.tecto.2018.12.010

Barba, D, Robin, C, Samaniego, P, Eissen, J-P (2008). Holocene recurrent explosive activity at Chimborazo volcano (Ecuador). $J$ Volcanol Geotherm Res 176(1):27-35. https://doi.org/10.1016/j.jvolgeores.2008.05.004

Barnard, PL, Hoover, D, Hubbard, DM, et al (2017). Extreme oceanographic forcing and coastal response due to the 2015-2016 El Niño. Nat. Commun. 8:14365. https://doi.org/10.1038/ncomms14365

Barriga-López, F (2015). Historia de los desastres naturales en el Ecuador : erupciones volcánicas, terremotos, cataclismos, tsunamis, inundaciones y más. Academia Nacional de Historia del Ecuador e Instituto Panamericano de Geografía e Historia Sección Nacional del Ecuador, Quito, Ecuador

Beate, B, Hillebrandt, C, Hall, ML (1990). Mapa de peligros volcánicos potenciales asociados con el volcán Chimborazo

Bernard, B (2013). Homemade ashmeter: a low-cost, high-efficiency solution to improve tephra field-data collection for contemporary explosive eruptions. J Appl Volcanol. 2:1. https://doi.org/10.1186/21915040-2-1

Biswas, S (2021). "Hanging" glacier broke off to trigger India flood. $B B C$ News

Bonadonna, C, Costa, A (2013). Plume height, volume, and classification of explosive volcanic eruptions based on the Weibull function. Bull Volcanol. 75:742. https://doi.org/10.1007/s00445-013-0742-1

Bonadonna, C, Houghton, BF (2005). Total grain-size distribution and volume of tephra-fall deposits. Bull Volcanol. 67:441-456. https://doi.org/10.1007/s00445-004-0386-2

Cáceres, B (2010). Actualización del inventario de tres casquetes glaciares del Ecuador. Inf Pasantía Investig En Univ Nice Sophia Antipolis

Chiarle, M, Iannotti, S, Mortara, G, Deline, P (2007). Recent debris flow occurrences associated with glaciers in the Alps. Glob Planet Change. https://doi.org/10.1016/j.gloplacha.2006.07.003

Cogley, JG (2009) A more complete version of the World Glacier Inventory. Ann Glaciol. 50(53):32-38 
Costa, JE, Williams, GP (1984). Debris-flow dynamics. sn, https://doi.org/10.3133/ofr84606

Delgado-Granados, H, Miranda, PJ, Núñez, GC, et al (2015). Hazards at IceClad Volcanoes: Phenomena, Processes, and Examples From Mexico, Colombia, Ecuador, and Chile. In: Snow and Ice-Related Hazards, Risks and Disasters. Elsevier, pp 607-646. https://doi.org/10.1016/B978-0-12-394849-6.00017-2

Eychenne, J, Le-Pennec, J-L (2012). Sigmoidal particle density distribution in a subplinian scoria fall deposit. Bull Volcanol. 74:2243-2249. https://doi.org/10.1007/s00445-012-0671-4

Favier, V, Wagnon, P, Chazarin, J-P, et al (2004). One-year measurements of surface heat budget on the ablation zone of Antizana Glacier 15 , Ecuadorian Andes. J Geophys Res Atmospheres. 109:D18, https://doi.org/10.1029/2003JD004359

Francou, B, Vuille, M, Favier, V, Cáceres, B (2004). New evidence for an ENSO impact on low-latitude glaciers: Antizana 15, Andes of Ecuador, 0 28' S. J Geophys Res Atmospheres. 109:D18. https://doi.org/10.1029/2003JD004484

Gaunt, HE, Burgisser, A, Mothes, PA, et al (2019). Triggering of the powerful 14 July 2013 Vulcanian explosion at Tungurahua Volcano, Ecuador. J Volcanol Geotherm Res. 392. 106762. https://doi.org/10.1016/j.jvolgeores.2019.106762

Hall, ML, Steele, AL, Bernard, B, et al (2015). Sequential plug formation, disintegration by Vulcanian explosions, and the generation of granular Pyroclastic Density Currents at Tungurahua volcano (2013-2014), Ecuador. J Volcanol Geotherm Res. 306:90-103. http://dx.doi.org/10.1016/j.jvolgeores.2015.09.009

Hidalgo, S, Battaglia, J, Arellano, S, et al (2015). SO2 degassing at Tungurahua volcano (Ecuador) between 2007 and 2013: Transition from continuous to episodic activity. $J$ Volcanol Geotherm Res. 298:1-14. https://doi.org/10.1016/j.jvolgeores.2015.03.022

IGEPN (2018). Tungurahua: monitoreo térmico y cambios morfológicos del cráter. In: VOLCÁN TUNGURAHUA Monit. Térm. Cambios Morfológicos Cráter. http://www.igepn.edu.ec/tungurahuainformes/\%20tung-campo/19943-monitoreo-termico-y-cambiosmorfologicos-del-crater-24-01-2018/file

IGEPN (2015). Actualización de la actividad del volcán Tungurahua, № 20 http://www.igepn.edu.ec/tungurahua-informes/tungespeciales/tung-e-2015/13803-informe-especial-tungurahua-n20/file. Accessed 24 Jan 2018

Jones, R, Manville, V, Andrade, D (2015). Probabilistic analysis of raintriggered lahar initiation at Tungurahua volcano. Bull Volcanol. 77:68. https://doi.org/10.1007/s00445-015-0946-7

Jordan, E, Hastenrath, SL (1998). Glaciers of South America: Glaciers of Ecuador. US Geol Surv Prof Pap

Lliboutry, L, Arnao, BM, Pautre, A, Schneider, B (1977a). Glaciological problems set by the control of dangerous lakes in Cordillera Blanca, Peru. I. Historical failures of morainic dams, their causes and prevention. J Glaciol 18:239-254

Lliboutry, L, Arnao, BM, Pautre A, Schneider, B (1977b). Glaciologica problems set by the control of dangerous lakes in Cordillera Blanca, Peru. I. Historical failures of morainic dams, their causes and prevention. J Glaciol 18:239-254

Maisincho, L (2015). Analyse de la fonte glaciaire et nivale dans les Andes tropicales à partir d'un bilan d'énergie: Glacier de l'Antisana, Equateur $\left(0^{\circ} 28^{\prime} \mathrm{S}\right)$. PhD Thesis, Grenoble Alpes
Manciati, C, Villacís, M, Taupin, J-D, et al (2014). Empirical mass balance modelling of South American tropical glaciers: case study of Antisana volcano, Ecuador. Hydrol Sci J. 59:8. 1519-1535. DOI: $10.1080 / 02626667.2014 .888490$

Mastin, LG, Randall, MJ, Schwaiger, HF, Denlinger, RP (2013). User's guide and reference to Ash3d: a three-dimensional model for Eulerian atmospheric tephra transport and deposition. US Geological Survey

McNutt, SR, Roman, DC (2015). Volcanic seismicity. In: The Encyclopedia of Volcanoes. Elsevier, pp 1011-1034

Mothes, P, Hall, ML, Andrade, D, et al (2004). Character, stratigraphy and magnitude of historical lahars of Cotopaxi volcano (Ecuador). Acta Vulcanol 16:1000-1023

Mothes, P, Yepes, HA, Hall, ML, et al (2015). The scientific-community interface over the fifteen-year eruptive episode of Tungurahua Volcano, Ecuador. J Appl Volcanol. $4: 9$. https://doi.org/10.1186/s13617-015-0025-y

Mulas, M, Chunga, K, Leon, D.O.G., Segovia, K.F.E. (2019). Sedimentological Study of Distal Rain-Triggered Lahars: The Case of West Coast of Ecuador. 26:17

Müller, F, Caflisch, T, Müller, G (1977). Instructions for compilation and assemblage of data for a World Glacier Inventory. Department of Geography, Swiss Federal Institute of Technology (ETH) Zurich

NAS (2017). Volcanic eruptions and their repose, unrest, precursors, and timing. Washington, DC: The National Academies Press. https://doi.org/10.17226/24650

Nie, Y, Pritchard, HD, Liu, Q, et al (2021). Glacial change and hydrological implications in the Himalaya and Karakoram. Nat Rev Earth Environ 2:91-106. https://doi.org/10.1038/s43017-020-00124-w

Okabe, A, Boots, B, Sugihara, K, Chiu, SN (2000). Spatial Tessellations: Concepts and Applications of Voronoi Diagrams. In: Geographical information systems. Wiley, UK

Parra, R, Bernard, B, Narváez, D, et al (2016). Eruption Source Parameters for forecasting ash dispersion and deposition from vulcanian eruptions at Tungurahua volcano: Insights from field data from the July 2013 eruption. $J$ Volcanol Geotherm Res 309:1-13. http://dx.doi.org/10.1016/j.jvolgeores.2015.11.001

Pierson, TC (1985). Initiation and flow behavior of the 1980 Pine Creek and Muddy river lahars, Mount St. Helens, Washington. Geol Soc Am Bull 96:(8). 1056-1069. https://doi.org/10.1130/00167606(1985)96<1056:IAFBOT>2.0.CO;2

Pierson, TC, Daag, AS, Delos Reyes, PJ, et al (1996). Flow and deposition of posteruption hot lahars on the east side of Mount Pinatubo, JulyOctober 1991. Fire Mud Erupt Lahars Mt Pinatubo Philipp 921950

Pistolesi, M, Cioni, R, Rosi, M, Aguilera, E (2014). Lahar hazard assessment in the southern drainage system of Cotopaxi volcano, Ecuador: Results from multiscale lahar simulations. Geomorphology 207:51-63. https://doi.org/10.1016/j.geomorph.2013.10.026

Rebetez, M, Lugon, R, Baeriswyl, P-A (1997). Climatic change and debris flows in high mountain regions: the case study of the Ritigraben torrent (Swiss Alps). In: Climatic Change at High Elevation Sites. Springer, pp 139-157. https://doi.org/10.1007/978-94-015-8905$5 \_8$

Samaniego, P, Barba, D, Robin, C, et al (2012). Eruptive history of Chimborazo volcano (Ecuador): A large, ice-capped and 
hazardous compound volcano in the Northern Andes. J Volcanol Geotherm Res 221:33-51. DOI:10.1016/j.jvolgeores.2012.01.014

Samaniego, P, Le-Pennec, J-L, Robin, C, Hidalgo, S (2011). Petrological analysis of the pre-eruptive magmatic process prior to the 2006 explosive eruptions at Tungurahua volcano (Ecuador). $J$ Volcanol Geotherm Res. 199:(1). 69-84. https://doi.org/10.1016/j.jvolgeores.2010.10.010

Schotterer, U, Grosjean, M, Stichler, W, et al (2003). Glaciers and climate in the Andes between the Equator and $30^{\circ} \mathrm{S}$ : what is recorded under extreme environmental conditions? In: Climate Variability and Change in High Elevation Regions: Past, Present \& Future. Springer, 15. pp 157-175. https://doi.org/10.1007/978-94-0151252-7_9

Scott, KM, Vallance, JW, Pringle, PT (1995). Sedimentology, behavior, and hazards of debris flows at Mount Rainier, Washington. US Geological Survey

Sierra, D, Vasconez, F, Andrade, SD, et al (2019). Historical Distal Lahar Deposits on the Remote Eastern-Drainage of Cotopaxi Volcano, Ecuador. J South Am Earth Sci 95:102251. https://doi.org/10.1016/j.jsames.2019.102251

Vallance, JW (2005). Volcanic debris flows. In: Debris-flow hazards and related phenomena. Springer Berlin, Heidelberg, pp 247-274. https://doi.org/10.1007/3-540-27129-5_10

Vasconez, F, Vásconez, R, Mothes, P (2017). Reconstrucción de los flujos de lodo del volcán Carihuairazo Originados por el terremoto de 1698 Utilizando el código VolcFlow. Conference: Jornadas en Ciencias de la Tierra 8, Quito, Ecuador, p 5

Vasconez, FJ, Maisincho, L, Cáceres, B, et al (2016). Mapa de amenazas potenciales por lahares secundarios quebrada Yamborumi - volcán Chimborazo

Waitt RB (2013). Lahar. Encycl Nat Hazards 579-580

\section{BIOGRAFÍAS}

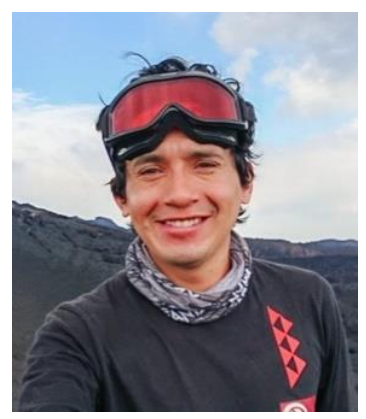

Vasconez, Francisco J. Nacido en Pujilí, el 12 de marzo de 1989. Ingeniero Geólogo de la Escuela Politécnica Nacional, promoción 2015. Se desempeña como investigador en el área de volcanología del Instituto Geofísico de la EPN. Sus líneas de investigación incluyen cuantificación de la amenaza volcánica, sensores remotos y modelamiento de fenómenos volcánicos, las cuales están soportadas por el manejo de sistemas de información geográfica. Además, Francisco se desempaña como geólogo de campo.
Maisincho, Luis. Doctor en Meteorología y Glaciología por la Université Grenoble Alpes (Francia), en la cual realizó la investigación sobre el impacto del cambio climático en los glaciares tropicales andinos en colaboración el Instituto Nacional de Meteorología (INAMHI), EPN, Instituto francés de cooperación para el Desarrollo (IRD), Laboratorio Mixto Internacional sobre Glaciares Recursos Agua en los Andes Tropicales (LMIGREATICE) y el observatorio mundial GLACIOCLIM. Luis es contraparte del IRD, responsable del eje clima-glaciar del LMI-GREATICE, director en Ecuador del GLACIOCLIM y director del área de estudios e investigación del INAMHI. Cuenta con 8 artículos indexados, 2 sometidos y 4 capítulos en libros.

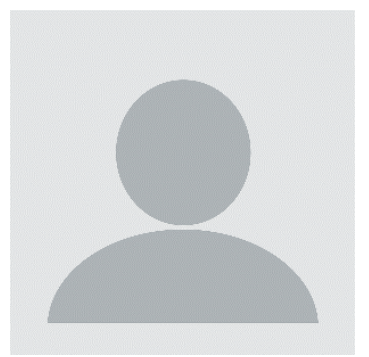

Andrade, S. Daniel. Ha recibido el grado de doctor (PhD) con especialidad en Volcanología de la Universidad Blaise Pascal de Clermont - Ferrand (Francia). Se desempeña como profesor principal de la facultad de ingeniería Geológica de la Escuela Politécnica Nacional. También es investigador del área de Volcanología del Instituto Geofísico de la EPN. En la actualidad está encargado de la jefatura del área de Volcanología del IG-EPN desde 2018.

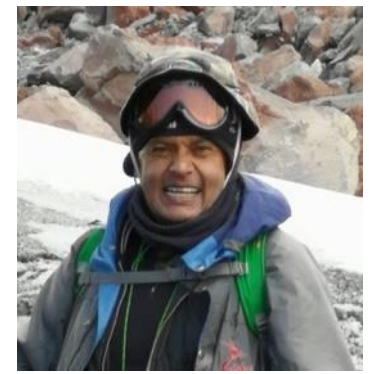

Cáceres Correa, Bolívar. Ingeniero Civil - Ingeniero en Geología (Universidad Central del Ecuador) - Maestría en riesgos asociados a Glaciares por la Universidad Sophia Antipolis (Francia). Responsable del Área de Glaciares en el INAMHI desde el año 2000. Corresponsal nacional para WGMS.

Responsable del área de estudios sobre la Criósfera en la Estación Antártica Ecuatoriana Pedro Vicente Maldonado 2010-2019 (9 campañas). Publicaciones referidas a estudios sobre la Criósfera a nivel nacional e internacional. Lead Author para SROCC-IPC ciclo R6. 


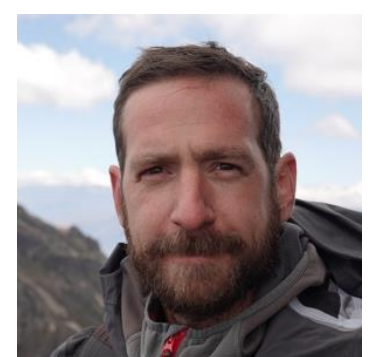

Bernard, Benjamin. Nacido en Chalon- sur-Saône-Francia, el 25 de septiembre de 1981. Ha recibido el grado de doctor $(\mathrm{PhD})$ con especialidad en Volcanología de la Universidad Blaise Pascal de Clermont - Ferrand (Francia). Se desempeña como docente de la facultad de ingeniería Geológica de la Escuela Politécnica Nacional. También es investigador del área de Volcanología del Instituto Geofísico de la EPN. Sus líneas de investigación son: depósitos volcánicos y dinamismos eruptivos, historia y evolución de volcanes, y evaluación de la amenaza volcánica.

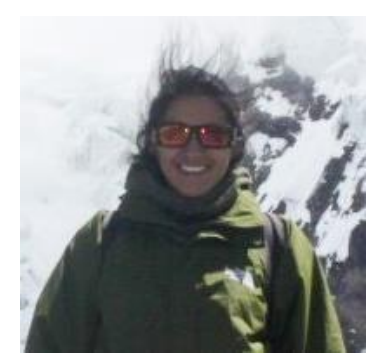

Argoti, Cristina. Nacida en Tulcán - Ecuador, el 9 de diciembre de 1991. Ingeniera Ambiental de la Escuela Politécnica Nacional, promoción 2018. Actualmente se desempeña en el ámbito de la consultoría ambiental e investigación de los efectos del cambio climático en los ecosistemas, especialmente en los glaciares y páramos de los Andes tropicales del Norte. Como parte de su área de investigación Cristina realiza actividades de campo y manejo de bases de datos en el software estadístico R.

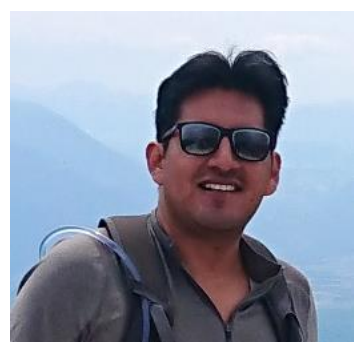

Telenchana, Edwin. Nacido en Quito-Ecuador, el 07 de abril de 1992. Ingeniero Geólogo de la Escuela Politécnica Nacional. Ha recibido el grado de Máster con especialidad en Geodinámica de la Université Grenoble Alpes (Francia). Se desempeñó como investigador en el área de Volcanología del Instituto Geofísico de la EPN. En la actualidad se desempeña como consultor independiente. Sus líneas de investigación son la geología, geodinámica y geocronología con énfasis en la datación mediante nucleidos cosmogénicos. Otras áreas de investigación son vulcanología, geoquímica y recurrencia de erupciones volcánicas.

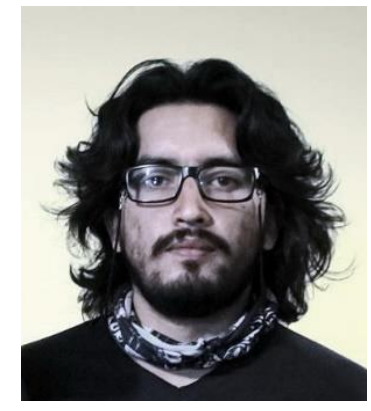

Almeida, Vaca Marco Andrés. Nacido en la Provincia de Tungurahua, el 26 de marzo de 1988. Ingeniero Geólogo de la Escuela Politécnica Nacional, promoción 2016. Se desempeña como geólogo en el área de volcanología del Instituto Geofísico de la EPN. Sus líneas de investigación se enfocan en la vigilancia de la actividad superficial de los volcanes activos y en erupción del Ecuador Continental y las Galápagos, en cuanto a: cambios morfológicos, anomalías termográficas y emisión de fluidos, todos ellos, enfocados en la evaluación de amenaza. Así mismo, Marco se desempeña como geólogo de campo y consultor independiente.

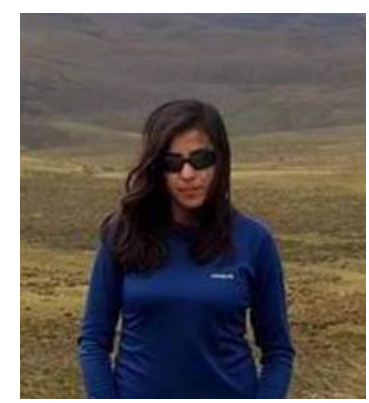

Almeida, Stefanie. Nacida en Tulcan - Ecuador, el 02 de febrero de 1991. Ingeniera Geóloga de la Escuela Politécnica Nacional, promoción 2016. Ha recibido el grado de Máster con especialidad en Riesgos Geológicos de la Universidad de Barcelona (España) en el año 2019. Se desempeñó como investigadora en el área de Volcanología del Instituto Geofísico de la EPN. Además, ha realizado estudios en tectónica activa y paleosismología. En la actualidad se desempeña como Especialista en Geología para proyectos energéticos en CELEC-EP. Sus líneas de investigación son la geología y riesgos geológicos.

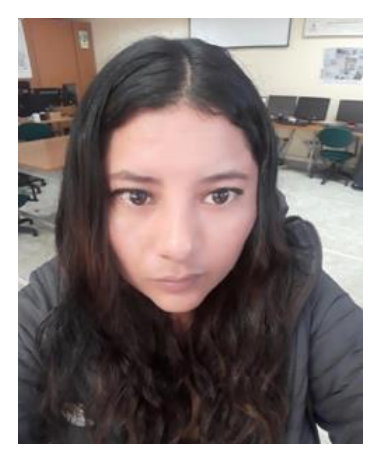

Lema, Verónica. Nacida en Quito, el 10 de octubre de 1986. Trabaja por más de 15 años en el Centro Terras, siendo parte del Instituto Geofísico de la Escuela Politécnica Nacional. Se especializa en el monitoreo y análisis de señales sísmicas de origen volcánico y tectónico. Verónica es la encargada de la vigilancia sísmica de los volcanes Cotopaxi y Chimborazo. Además, realiza turnos de monitoreo en los cuales se reporta la ocurrencia de fenómenos volcánicos y eventos tectónicos en el Ecuador continental y Galápagos. 
Revista Politécnica, Agosto - Octubre 2021, Vol. 48, No. 1 